\title{
Spectral domain optical coherence tomography study of pearl-like lesions in the anterior chamber
}

This article was published in the following Dove Press journal:

Clinical Ophthalmology

12 June 2012

Number of times this article has been viewed

\section{Wael Soliman* \\ Ehab I Wasfi* \\ Omar M Ali}

Department of Ophthalmology, Assiut University Hospital, Assiut University, Assiut, Egypt

*These authors contributed equally to this work
Correspondence: Wael Soliman Department of Ophthalmology, Assiut University Hospital, Assiut University, Assiut, Egypt Tel +20 I6 5566530 Email waelsoliman73@yahoo.com
Aim: To study the morphological pattern of pearl-like lesions in the anterior chambers of children before and after management using anterior segment spectral domain optical coherence tomography (SD-OCT).

Patients and methods: This was a prospective, observational cross-sectional study of patients presenting with peculiar pearl-like lesions in the anterior chamber of their eyes. $1 \mathrm{~mL}$ of betamethasone sodium phosphate $(2 \mathrm{mg} / \mathrm{mL})$ and betamethasone dipropionate $(5 \mathrm{mg} / \mathrm{mL})$ was injected subconjunctivally. Follow-ups of all patients were conducted for a period of 6 weeks. Anterior segment imaging was done using SD-OCT and also photo slit lamp before and after management.

Results: Twelve eyes of 12 patients were included in this study. These patients presented with pearl-like lesions in the anterior chamber with signs of anterior uveitis. There was no history of ocular injury or tuberculosis in any patients. Six weeks after subconjunctival steroid injection, all patients achieved mean best-corrected visual acuity, which changed from 0.2 (range $0.1-0.4$ ) to 0.5 (range $0.4-0.8$ ), and the severity of iritis decreased. SD-OCT showed that the lesions at presentation appeared as a globular noncystic mass attached to the back of the cornea, encroaching on the angle of the eye, and attached to the anterior surface of the iris at some points.

Conclusion: SD-OCT for imaging the anterior segment allowed us to exclude the cystic nature of this pearly lesion. Some similarities may exist between these pearly lesions and superficial phlyctenular keratitis, which may support the immunological and inflammatory origin of these lesions.

Keywords: pearl-like lesions, anterior chamber, phlycten, anterior segment OCT

\section{Introduction}

Pearl-like lesions in the anterior chamber of children's eyes are common peculiar eye entities that are seen frequently by ophthalmologists in the southern part of Egypt. They usually present as a unilateral nodule, occupying an area between the 5 and 7 o'clock positions, and are usually yellowish or grayish pearly white in colour.

The pearly lesions are always accompanied by a clinical picture of anterior uveitis, are very resistant to treatment with topical steroids, and tend to recur.

These pearly lesions were first reported by Ahmed and Kroosh in 1994. ${ }^{1,2}$ They also reported the chronic nongranulomatous inflammatory histopathology of these pearly lesions. In 1942, Gibson suggested the term "posterior phlyctenular keratitis" for a pearly lesion in the anterior chamber in a woman with previous anterior phlyctenular keratitis, due to similarities between the two lesions. ${ }^{3}$

Spectral domain optical coherence tomography (SD-OCT), introduced in 2002, provides detailed cross-sectional images of structures in biological tissues with an 
axial resolution of 5 microns and a transverse resolution of 15 microns. ${ }^{4,5}$ Although the instrument was designed primarily to examine the posterior segment, imaging of the anterior segment was achieved by adjusting an anterior module to the same device. ${ }^{6}$

The aim of this work was to study the morphological pattern of these pearl-like lesions before and after management using anterior segment SD-OCT.

\section{Patients and methods}

The study was done at Assiut University Hospital and Al-Noor Eye Investigation Center, Assiut, Egypt. In this observational prospective study, patients presenting with pearl-like lesions in the anterior chamber of their eyes were included. This study was done from September 2009 to September 2010.

Twelve eyes of 12 patients (two females and ten males) were included in this study. The mean age of included patients was 11 years (range 9-16 years). All patients originated from rural areas and were of low socioeconomic status.

A full history of previous ocular injury, surgery, or disease; previous medical history; and history of medicine administration were taken. Tests for tuberculosis (tuberculin skin testing) and stool analyses were done for all patients. Best-corrected visual acuity was measured and the anterior and posterior segments of the eye were clinically examined with a slit lamp (BM $900^{\circledR}$; HAAG-STREIT AG, Koeniz, Switzerland). Intraocular pressure was measured using a Goldmann tonometer (AT $900^{\circledR}$; HAAG-STREIT) and gonioscopy.

We performed anterior segment imaging using a photo slit lamp and SD-OCT (RTVue-100; Optovue, Freemont, CA). SD-OCT uses two lens attachments, the cornea/anterior module-short (CAM-S) and CAM-long (CAM-L), to obtain anterior segment images. The CAM-S attachment provides a high-magnification view, whereas the CAM-L provides a wider viewing angle but at a slightly decreased resolution. We also used integrated analysis software (RTVue-100) for subsequent analysis.

In SD-OCT vertical and horizontal, raster default scans were taken using $6 \mathrm{~mm}$ scan lines using a CAM-L add-on lens with axial resolution of $5 \mu \mathrm{m}$. The nature of the treatment, including benefits and risks, was explained clearly to all parents of the children, and written consents were signed. The study was undertaken with the approval of the institutional board of ethics (Assiut University Hospital, Assiut, Egypt).

$1 \mathrm{~mL}$ of betamethasone sodium phosphate $(2 \mathrm{mg} /$ $\mathrm{ml})$ and betamethasone dipropionate $(5 \mathrm{mg} / \mathrm{mL})$ plus $0.1 \mathrm{~mL}$ of mepivacaine $\mathrm{HCL} 3 \%$ was injected in the lower fornix subconjunctivally after giving benoxinate hydrochloride $0.4 \%$ as a topical anesthetic three times at 2-minute intervals.

All patients were given a topical steroid (prednisolone acetate), eyedrops three times daily with gradual withdrawal, and mydriatic cycloplegic (Cyclopentolate 1\%) eyedrops for 6 weeks after steroid injection.

Patient follow-ups occurred for a total period of 6 weeks, and patients were seen two times during this period (at the first week and sixth week).

\section{Results}

Patients in this study presented with pearl-like lesions in the anterior chamber with signs of anterior uveitis. There was no history of eye injury in any patients. None of our patients were positive for tuberculosis. Entamoeba histolytica, Hymenolepis nana, and Giardia lamblia were detected in the stool of three of our study group.

The mean best-corrected visual acuity at presentation was 0.2 decimal notation (range $0.1-0.4$ ). At 6 weeks, all patients achieved mean best-corrected visual acuity of 0.5 (range 0.4-0.8).

The severity of uveitis was variable, as four eyes showed severe (+4) iritis, and eight eyes showed moderate iritis (+3) (Table 1). The intraocular pressure at the first presentation and follow-up visits was normal in all patients.

One week after steroid injection, the severity of iritis decreased to mild $(+1)$ in seven patients, and five patients showed absence of active iritis. By the sixth week, 12 patients showed no cells in the anterior chamber (Table 1). One week after the resolution of the first pearl-like lesion, a patient came with a recurrent lesion beside the old one with iritis (+3) (Figure 1).

Six weeks after steroid injection, the size of the lesions was markedly decreased: by more than $50 \%$ in all patients, except in one patient who had developed large heavy vascularization of the lesion (Figure 2).

Four patients presented with a pear-shaped pupil that did not change after steroid injection (Figures 1, 4 and 5).

Anterior segment SD-OCT was performed on all included patients before and 6 weeks after treatment. Anterior segment SD-OCT scans showed that the nontreated pearl-like lesion appeared as a globular noncystic mass attached to the back of the cornea, encroaching on the angle of the eye and attached also to the anterior surface of the iris (Figures 3 and 4). Six weeks after treatment, the treated lesion appeared as a flat mass closing the angle of the eye and adherent to both the back of the cornea and the front surface of the iris (Figure 3). 
Table I Severity of iritis at baseline examination and after treatment

\begin{tabular}{|c|c|c|c|c|}
\hline \multirow[t]{2}{*}{$\begin{array}{l}\text { Follow-up/ } \\
\text { patients }\end{array}$} & \multicolumn{3}{|c|}{$\begin{array}{l}\text { Severity of iritis } \\
\text { (aqueous cells) }\end{array}$} & \multirow{2}{*}{$\begin{array}{l}\text { Changes of pearl- } \\
\text { like mass at week } 6 \\
\text { of follow-up }\end{array}$} \\
\hline & Baseline & Week I & Week 6 & \\
\hline I & +4 & - & - & $\begin{array}{l}\text { Healed and } \\
\text { decreased in size }\end{array}$ \\
\hline 2 & +4 & +1 & - & $\begin{array}{l}\text { Healed and } \\
\text { decreased in size }\end{array}$ \\
\hline 3 & +3 & +1 & - & $\begin{array}{l}\text { Healed and } \\
\text { decreased in size }\end{array}$ \\
\hline 4 & +4 & +1 & - & $\begin{array}{l}\text { Healed and } \\
\text { decreased in size }\end{array}$ \\
\hline 5 & +3 & +1 & - & $\begin{array}{l}\text { Healed and } \\
\text { decreased in size }\end{array}$ \\
\hline 6 & +4 & - & - & $\begin{array}{l}\text { Healed and } \\
\text { decreased in size }\end{array}$ \\
\hline 7 & +3 & +1 & - & $\begin{array}{l}\text { Healed and } \\
\text { decreased in size }\end{array}$ \\
\hline 8 & +3 & +1 & - & $\begin{array}{l}\text { Healed and } \\
\text { decreased in size }\end{array}$ \\
\hline 9 & +3 & - & - & $\begin{array}{l}\text { Healed and } \\
\text { decreased in size }\end{array}$ \\
\hline 10 & +3 & - & - & $\begin{array}{l}\text { Healed and } \\
\text { decreased in size }\end{array}$ \\
\hline II & +3 & - & - & $\begin{array}{l}\text { Healed and } \\
\text { decreased in size }\end{array}$ \\
\hline 12 & +3 & +1 & - & $\begin{array}{l}\text { Healed and } \\
\text { decreased in size }\end{array}$ \\
\hline
\end{tabular}

\section{Discussion}

There are many queries that need to be clarified in this controversial subject. Gibson suggested the term "posterior phlyctenular keratitis" for a pearly lesion in the anterior chamber in a woman with previous superficial phlyctenular keratitis. He also described that this lesion was a low-grade allergic inflammatory process deep in the cornea. ${ }^{3}$

In 1994, Kroosh and Ahmed ${ }^{2}$ concluded that there was no cyst wall found whatsoever in each of the samples removed from 34 eyes, and also confirmed the presence of lymphocytes, polymorphonuclear leucocytes, pus cells, RBCs with some histocytes, and plasma cells. The examination of the excised specimens revealed the presence of chronic nongranulomatous inflammatory cells, and added that adherence of some iris to the cornea with the presence of fibrin also supported the view towards an inflammatory and immunological nature of this lesion.

In our study, all of the patients presented with the clinical picture of "iridocyclitis," which included pain, photophobia, reduced vision, and ciliary injection. The signs were associated with severe inflammatory reaction in the anterior chamber $(+3$ or +4$)$ with aqueous flare, and four patients presented

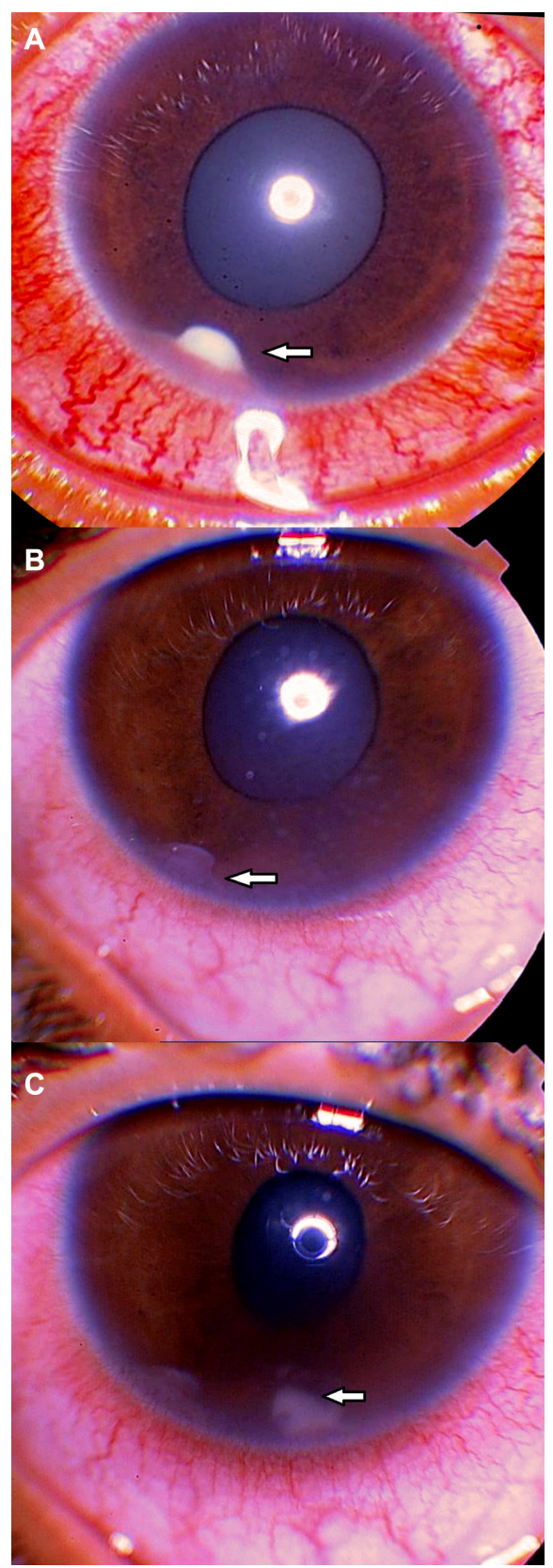

Figure I (A) The first presentation of a patient of II years old with a pearl-like lesion in the anterior chamber (arrow) at 7 o'clock with ciliary injection and a pearshaped pupil; (B) the presentation of the same patient after 6 weeks of treatment by subconjunctival and topical steroids with a decrease in the size of the lesion (arrow) and of the ciliary injection with some old keratic precipitates; and (C) the appearance of a new lesion in the anterior chamber (arrow) at 6 o'clock in the same patient I week after resolution of the first pearl-like lesion.

with pupil distortion. The similarity between the clinical picture of such cases and that of iridocyclitis, and the predilection to the lower part of the iris, gave an impression that these lesions are due to an inflammation inside the eye.

There have been many reports ${ }^{7-12}$ about iris cysts, both primary and secondary, in children. Primary cysts have shown a more benign course, and secondary ones a more 


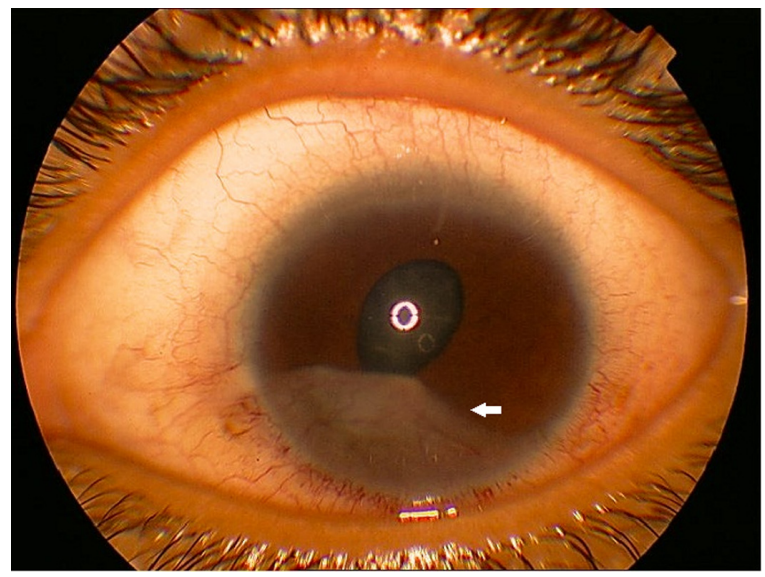

Figure 2 Enlargement and heavy vascularization of one of the treated pearl-like lesions (arrow) six weeks after treatment by subconjunctival and topical steroids. Note: This figure also shows the persistence of the pear-shaped pupil.

aggressive and inflammatory course. It has also been reported that primary epithelial cysts have a more benign clinical course than primary stromal cysts. ${ }^{7-12}$ Secondary iris cysts have been mainly associated with uveitis. ${ }^{7-11}$ Moreover, most of the reported iris cyst cases with a pearl-like appearance were secondary cysts. ${ }^{12-15}$

As all anterior chamber lesions in this study had pearly appearance and were associated with anterior uveitis, we thought that these lesions could be secondary cysts. To confirm the noncystic pattern for these lesions, we did anterior segment SD-OCT, which allowed us to show that lesions included in our study were solid in nature and not cystic, and we were able to exclude this possibility in all included patients.

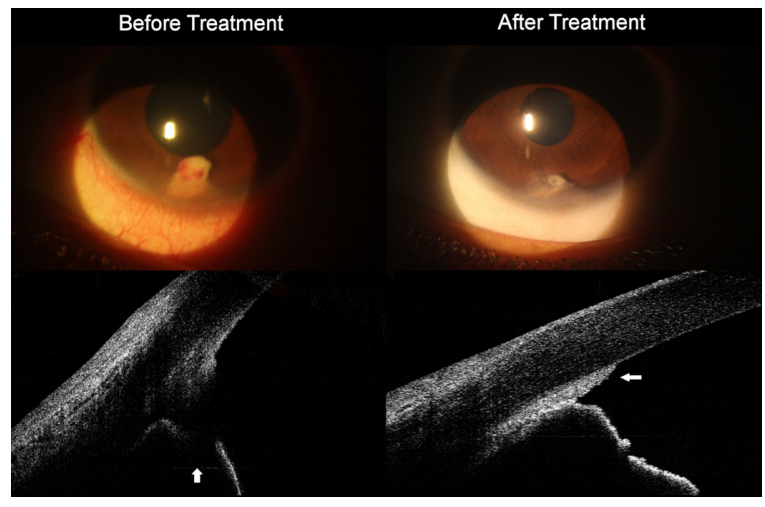

Figure 3 Vertical scans of anterior segment SD-OCT images of pearl-like lesion at the anterior chamber at 6 o'clock.

Notes: Before treatment, the SD-OCT showed a highly reflective globular noncystic mass attached to the back of the cornea and causing shadowing to the iris tissue behind it. After treatment with subconjunctival and topical steroids, the SD-OCT showed a flat, highly reflective mass closing the angle of the eye and adherent to both the back of the cornea and the front surface of the iris.

Abbreviation: SD-OCT, spectral domain optical coherence tomography.

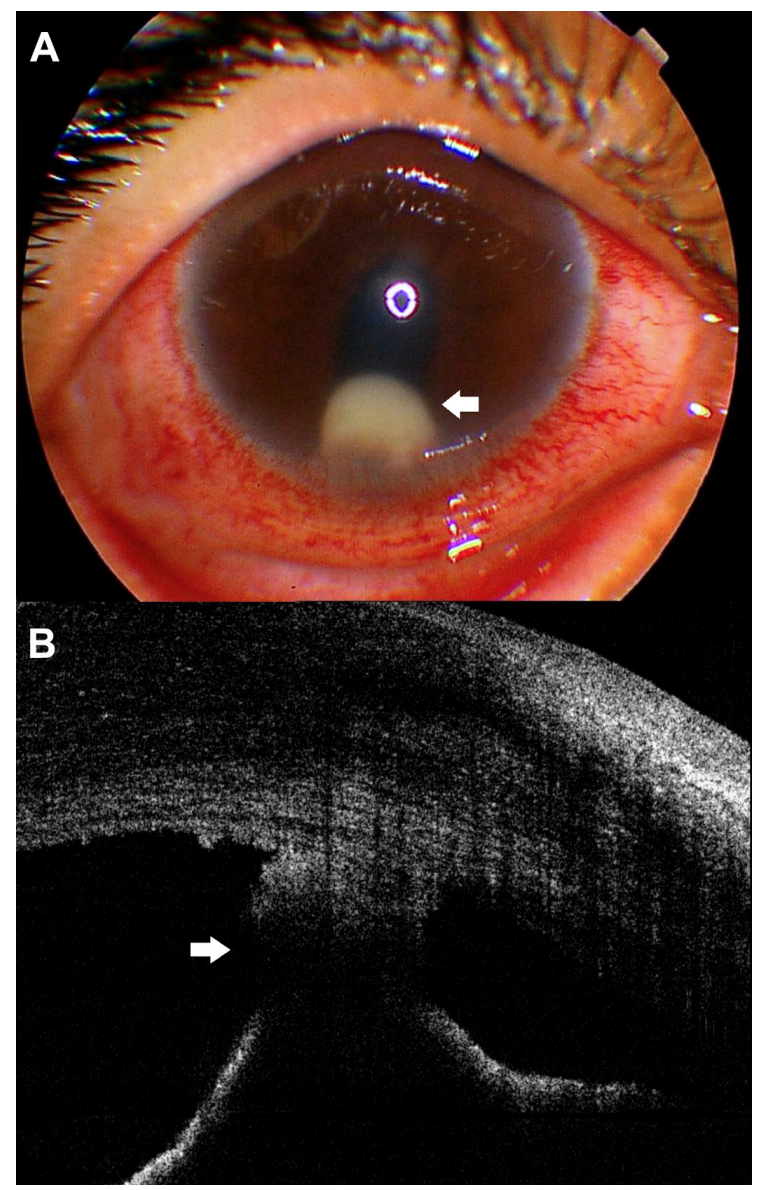

Figure 4 Horizontal scan of anterior segment SD-OCT image of a nontreated pearl-like lesion at the anterior chamber at 6 o'clock showing a highly reflective globular noncystic mass (arrow) attached to the back of the cornea and causing shadowing to the underlying iris.

Note: This SD-OCT image also shows highly reflective small masses, that could be keratic precipitates, at the back of the cornea, to the left of previously described lesion. Abbreviation: SD-OCT, spectral domain optical coherence tomography.

Accordingly, it is highly unlikely that these lesions are iris or implantation cysts, and the favorable response to steroids, especially subconjunctival injection of combined short- and long-acting betamethasone, points to the probability that this pearl-like lesion is an immunological reaction to an unknown antigen, especially given that most of our patients were old enough to exclude the congenital nature of these lesions.

Entamaeba histolytica, Hymenolepis nana and Enterobius vermicularis were among the implicated organisms causing phlyctenulosis. ${ }^{16,17}$ The former two of these parasites were found in the stool analyses of two children who had pearl-like lesions in our study, and these patients were malnourished and underweight.

Some similarities may exist between these lesions and phlyctenulosis. Both conditions occur in children living in poor socioeconomic standards; are recurrent; present as grayish-white circumscribed lesions in the vicinity of 


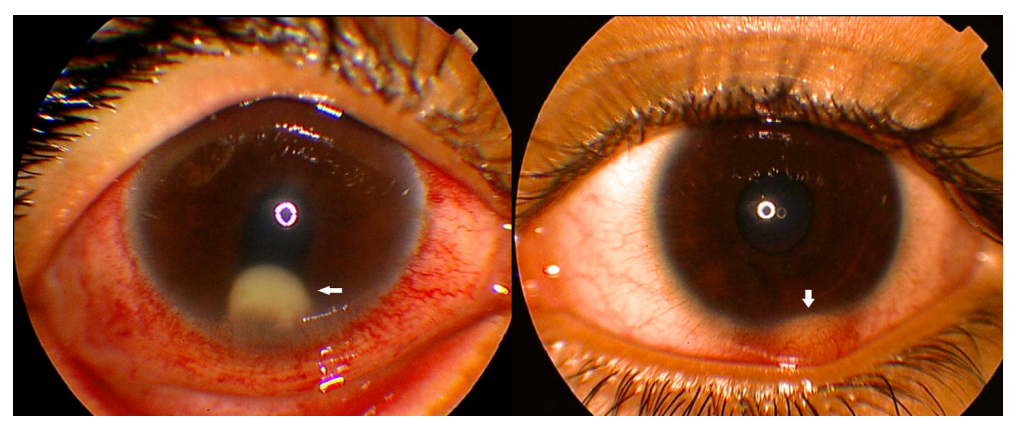

Figure 5 (Right) The similarity in location between the phlycten (superficial phlyctenular keratitis; arrow); and (Left) a pearl-like lesion in the anterior chamber (arrow), which may be a form of posterior phlyctenular keratitis.

Note: Both conditions can be seen presenting as a grayish-white circumscribed lesion in the vicinity of the limbus.

the limbus; and respond to steroid treatment. According to these findings, we think that malnourishment and parasitic infestation may have a role in the occurrence of these pearllike lesions.

SD-OCT imaging of the anterior segment allowed us to exclude the cystic nature of this lesion and to solve in great part this mysterious finding. Also, the SD-OCT gave an interpretation for the pear-shaped pupil appearance that was associated with these lesions by showing the contact between these lesions and the front surface of the iris both before and after treatment (Figures 3 and 4).

This pearly lesion in the anterior chamber could be a posterior form of phlyctenular keratitis, and future studies are needed to confirm the correlation between well-known superficial phlyctenular keratitis and these anterior chamber pearl-like lesions (Figure 5).

\section{Disclosure}

The authors report no conflicts of interest in this work.

\section{References}

1. Ahmed AA, Ali OM. Management of health tumour like lesion of the anterior chamber. New Egypt J Med. 1994;10:1613-1616.

2. Kroosh S, Ahmed A. Histopathology and cytology anterior chamber pearl tumour like lesion. New Egypt J Med. 1994;10:1609-1612.

3. Gibson GG. Posterior phlyctenular keratitis. Society transactions: College of Physicians of Philadelphia, section on ophthalmology. Arch Ophthal. 1942;29:159-166.

4. Wojtkowski M, Leitgeb R, Kowalczyk A, Bajraszewski T, Fercher AF. In vivo human retinal imaging by Fourier domain optical coherence tomography. J Biomed Opt. 2002;7:457-463.
5. Wojtkowski M, Bajraszewski T, Targowski P, Kowalczyk A. Real-time in vivo imaging by high-speed spectral optical coherence tomography. Opt Lett. 2003;28:1745-1747.

6. Sarunic MV, Asrani S, Izatt JA. Imaging the ocular anterior segment with real-time, full-range Fourier-domain optical coherence tomography. Arch Ophthalmol. 2008;126:537-542.

7. Lois N, Shields CL, Shields JA, Mercado G. Primary cysts of the iris pigment epithelium. Clinical features and natural course in 234 patients. Ophthalmology. 1998;105:1879-1885.

8. Lois N, Shields CL, Shields JA, Mercado G, De Potter P. Primary iris stromal cysts. A report of 17 cases. Ophthalmology. 1998;105: 1317-1322.

9. Shields JA. Primary cysts of the iris. Trans Am Ophthalmol Soc. 1981; 79:771-809.

10. Shields JA, Kline MW, Augsburger JJ. Primary iris cysts: a review of the literature and report of 62 cases. Br J Ophthalmol. 1984;68:152-166.

11. Shields JA, Shields CL, Lois N, Mercado G. Iris cysts in children: classification, incidence, and management. The 1998 Torrence A Makley Jr Lecture. Br J Ophthalmol. 1999;83:334-338.

12. Eagle RC Jr, Shields JA, Canny CL, Thompson RL. Intraocular wooden foreign body clinically resembling a pearl cyst. Arch Ophthalmol. 1977;95:835-836.

13. Morán M, Dvorák V, Jezdinská V. Pearl cyst of the iris. Cesk Oftalmol. 1968;24:51-54. Czech.

14. Sitchevska O, Payne BF. Pearl cysts of the iris. Am J Ophthalmol. 1951; 34:833-840

15. Sitchevska O. Perforating injury of the eye. Implantation of cilia in iris followed by formation of pearl cyst. J Am Med Womens Assoc. 1951;6: 233-234.

16. Al-Hussaini MK, Khalifa R, Al-Ansary AT, Hussain GH, Moustafa KM. Phlyctenular eye disease in association with Hymenolepis nana in Egypt. Br J Ophthalmol. 1979;63:627-631.

17. Hussein AA, Nasr ME. The role of parasitic infection in the aetiology of phlyctenular eye disease. J Egypt Soc Parasitol. 1991;21:865-868.
Clinical Ophthalmology

\section{Publish your work in this journal}

Clinical Ophthalmology is an international, peer-reviewed journal covering all subspecialties within ophthalmology. Key topics include: Optometry; Visual science; Pharmacology and drug therapy in eye diseases; Basic Sciences; Primary and Secondary eye care; Patient Safety and Quality of Care Improvements. This journal is indexed on
PubMed Central and CAS, and is the official journal of The Society of Clinical Ophthalmology (SCO). The manuscript management system is completely online and includes a very quick and fair peer-review system, which is all easy to use. Visit http://www.dovepress.com/ testimonials.php to read real quotes from published authors. 